dynamite was exploded below water, which caused the great-
est consternation. A further progress up the river was est consternation. A further progress up the river was
stopped by the fact of the Ellangovoan breaking the shank of herpropeller.
The second paper furnished an account of $\mathrm{Mr}$. Octavius $\mathrm{C}$. Moresby, in the east part of that island. It brought to notice
Mones tives of a superior character to the coast tribes, and well distives of a superior character to the coast tribes, and well dis-
posed and friendly to white men. It was greatly to be wished posed and friendly to white men. It was greatly to be wished
that no kidnapping parties would be allowed to exercise their
nefarious tratric there, and so raise a bar against the possibility of future friendly intercourse between the two races.
In the short discussion which followed admiration was freely In the short discussion which followed admiration was freely
expressed at the successful manner in which Mr. Macfarlane had journeyed into the interior without bloodshed. INSTITUTION OF CIVIL ENGINEERS.

ON March 21st a paper was reud descriptive of “The Hy-
draulic Canal Lift at Anderton, on the River Weaver," by Mr. draulic Canal Lift at Anderton, on the River Weaver," by Mr.
Sidenglam Due, B. Sc., Assoc. Inst. C.E.
The object of this lift was to transfer floating barges between the Trent and Nersey Canal and the river Weuver, and
thus to afford an easy and expeditious means of communicathus to afford an easy and expeditious means of communica-
tion between them without the expense and delay hitherto
incurred in transhipping goods. The idea of lifung the laden incurred in transhipping goods. The idea of lifung the laden
barges by lydraulic power originated with Mr. Edward Leader
Williams, Jr., M. Inst. C.E., at that time engineer to the trusWilliams, Jr., M. Inst. C.E., at that time engineer to the trusClark, M. Inst. C.E., on the subject, and after various designs
lad been considered, the arrangement of the details and the superintendence of the construction were entrusted to the
author. The canal and river were close together at Anderton, but the level of the water in the canal was $50 \mathrm{ft} .4 \mathrm{in}$. above that in the river.
The water of the canal was conducted by a wroughtitiron
aqueduct, $162 \mathrm{ft}$. $6 \mathrm{in}$. long, across an arm of the river to the end of the lift. This aqueduct was in three spans, of $30 \mathrm{ft}$.
7.j $\mathrm{ft}$., and $57 \mathrm{ft}$. 6 in. It was $34 \mathrm{ft} .4$ in. wide, and a centrul web divided it into tw.s channels, each $17 \mathrm{ft} .2$ in. wide. This cen-
tral web and the sides of the aqueduct were $8 \mathrm{ft}$. 6 in. deep, and formed continuous girders, which carried the aqueduct weight of the aqueduct and the water was 1050 tons, or about
$6 \frac{1}{2}$ tons per lineal foot. Excepting at thro end, where it rested on the masonry of a busin leading into the canal, the aqueduct
on the was carried on cast iron columns.
The lift was double; eacl half consisted of a wrought-iron trough $75 \mathrm{ft}$. long and $15 \mathrm{ft}$. 6 in. wide, capable of containing and formed girders to carry the weight of the trough, water, and barges, which amounted to 240 tons. This weight was transmitted from the sides to the head of a central ram, 3 ft. in diameter, by cantilevers which radiated from the ram to the
sides of the trough. The trough was thus supported and moved up and down by one central vertical ram, which $43 \mathrm{cwt}$. per square incl. The trougl laud a lifing gate about 4. cwt. per square inch. T'he trought had a litting gate at each
end, for the ingress and egress of barres, and there were cor-
respondimg gates in the aqueduct, so that boats could pass be responding gates in the aqueduct, so that boats could pass be-
iween the aqueduct and the trough according as they were to ¿ween the aqueduct and the trough accordmg as they were to
be lowered or haid been lifted. The press under one trough
was connected by a pipe, 5 in. in diameter, with that under the other trough, and thus water contained in one could pass There was also a small steam-engine continually pumping water into an accumulator, to assist in the working of a lift.
Piping 4 in. in diameter passed from the accumulator to eacl of the presses, and the accumulator could be opened to either
of the presses as required. All the ralves lor working this on the top of the aqueduct. In working this lift, when one on the top of the aqueduct. In working this lift, when one
trough containing barges and water $5 \mathrm{ft}$. deep was at the top
of the lift, the otlier, containing barges and water $4 \mathrm{ft} .6 \mathrm{ill}$. deep. was in the river below. As the npper trough was
lheavier than the lower onle, it followed that as soon as the valve on the 5-ine pipe was opened, the upper trough descended
and lifted the lightiter one out of the river, until, by becoming in its turn immersed in the river below, it lost part of its in its turn immersed in the river below, it lost part of its
gravitation, and forced the lighter trough to within 4 ft. 6 in.
of the top of the. lift. The valve on the 5-in. pipe was now closed, and the remaining water in the press under the descending trough was allowed to run to waste into the aque-
duct. The trough consequently descender into the river, and the barges it contained liad bern lowered from the canal to
the river. Whilst this was going on the accumulator was opened to the press of the ascending trough, and this trougl
and barges were raised to within 6 in. of the top of the lift. The burges were lifted the remaining 6 in. by letting this dept
of water in to the irough from the aqueduct. Thus a deptll o of water into the trough from the aqueduct. Thus a depth of
6 in. of water over the area of the trough taken from the to the river, and at the same time, with a little assistance from Automatic syplons insurid a depth of $4 \mathrm{ft}$. 6 in. of water in an ascending trough. The edges of the gates were kept water-
tight with india-rubber, and the same material was used for making a joint between the troughs and the end of the aque
duct. The time required to lower one trough and to lilt the other was three minutes, ancl the whole operation of transferother was three minutes, anct the whole operation of transfer
timge from the river to the canal was eight minutes ant chain of locks at Runcorn having the same fall a boat could only pass one way in one hour and a half. A very small staff
was required to work the apparatus, and the total weekly exwas required to work the apparatus, and the total weekly ex
penses did not exceed $£ 10$. In addition to the time saved by this lift compared with a flight of locks having the same fall,
it was stated that when the traffic was equal in each direction it was stated that when the traffic was equal in each direction,
only 6 in. of water over the area of the trough were used,
instead of $50 \mathrm{ft}$. required by the locks. The lift was publicly op, ned by the trustees in July, 1875, and had given great s; tisfaction. The iron-work and machinery were constructed by Messrs. Emerson, Murgatroyd \&
Co., of Stockport and Liverpool, and the foundations, masonry
basing etc. were carried out by Inst. C.E., the present engineer to the Weaver Trustees.

\section{ELECTRO-MOTIVE ENGINES}

THE invention of Mr. E. Burgin, of Paris, consists of cartain pecuinar methods of constructing and arranging the ele-
ments or electro-magnets forming the generating cylinders of magneto-electric machines, and to the modes of lapping currents of quantity or of tension are obtained. The same
apparatus is applicable as an electro-motor when excited by a battery or magneto-electric machine.
NECESSITY FOR MORE SKILLED ARTISANS. By JaMes M. Blanchatid.

THE necessity for the acquirement of greater skill by the one, and all classes of people are, or should be, interested in aving provision made for acquiring such skill. While it is
rue that we have many artisans whose attainments will compare favorably with persons standing at the head of sinilar
occupations in other countries, and who are an honor to them occupations in other countries, and who are an honor to them-
selves and to the country, yet it is equally true that a arge pro-
portion of the class referred to are not in the possession of the requisite amount of skill to enable them to compete successfully with their more fortunate rivals. This condition in
which they find themselves plucet has grown out of two very popular but very grievous eriors : First, the prevailing be-
lief that any person of mediocre talent and acquirements who can not afford to educate limself for some protession, is quite
fit for an artisan; and secondly, that any person having a fair endowment of natural abilities, but little or no education, is quite capable of becoming a successful mechanic.
It is these two prevailing opinions that have driven into the ranks of artisans so many persons who have not had the relooded the market with unskilled labor. Before proceeding
fyrther it may be well to define what is meant by, or what The answer to this is plain and can be artisan.
The

The answer to this is plain. and can be given in one wordtraining. But the requisite or proper training is of a duplex
character ; it is not enought that a person is skilled in the use of tools or the implements necessary to enable him to give
form to whatever he may be engaged upon, he must also be trained to scientific methods of thinking and reasoning, so
that when an idea is suggestel the reasoning faculties
may determine its correctness or error, in order that the hands may be relieved from the necessity of doing a large amount
of unnecessary labor in determining facts which it is pro-
perly the province of the mind to do. It follows, then, that to enable a person to become a skilled artisan, he must first
a d become a scientist to such an extent as to be able to under-
stund fully the character and composition of the material which he may be called ul and to manipulate, in order that he
way be able to select the bes: for lis purpose, and in order hat he may logically and correctly determine the effects of

As necessary as the education above hinted at is, a perso
may possess it all and yet be very far from being a skilled
rtisan. He must add to such acquirements a thorough practical knowledge of the art in whichl he proposes to engage and hence the duplex trainin $y$ becom
in the production of a skilled artisan.

Having shown the necessity for a thorough training of that mains to point out how such training may be had und paid
for in order that the poorest in worldly goods may avail themThe of the advantages it off ers.

The writer is well aware that, as a rule, the class of people
he is speaking of are not able to send their sons to the scliools theoretical hart only of the truining required, the services tir sucherical pourt being anly of the training required ; the services of
family, they must be put where they to the support of the
fan be earners of mones, and not spenders; but, were this otherwise, thee are no
schools within the reach of the poorer classes where bothl schools within the reach of the poorer classes where both
branches of the training i eferred to can be liad; and as a consequence, a person desiring to fit limself for the greatest
amount of usefulness as an artisan must first spend years in amount of usefulness as an artisict must first spend years in
acquiring what is called an education. after which he must
"learn a trade," a process which involves the expenditure of an unnecessiry amount of time and money.
what seems to be r.quired for the benefit of

What seems to be $r$ quired for the benefit of this class of
persons is the establislment of one or more polytechnic ad by allowing the student to divide his time between can be had by allowing the student to divide his time between labor
and study, a portion of each day beting devoted to each, thus enabling him to acquire in five yerrs what it would require

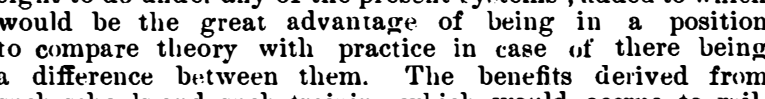
a difference bet ween them. The benefits derived from
such schools and such training which would accrue to rail road compranies, and to private employers of the people thus
educated, would be incalculable, as it would enable them to educated, would be incalculable, as it would enable them to
provide their establislments with a class of men who are in
possession of facts, and who would be able to determine at possession of facts, and who would be able to determine at
once what pretended improvements to adopt and what to re-
jet ject; at the same time it would enable them to lave the
greatest amount of work done with the least possible outlay of money for shops and tools. Every observant employer
knows that when he emplors two mechanics for the same
kind of work, even though they may be physically the equals kind of work, even though they may be physically the equals
each of the other, he does not get the same character or quan each of the other, he does not get the same character or quan-
tity of work from both, and the reason is that one is more
skilful than the other, and it, is probable that he is in advance of his fellow in this respect because lie has been more methodi brains; and it is also probable that had both of these parties been trained in a school where one method of thoughit and as well as the profits of the employer. hown, it remains to be shown how the facilities for acquiring it can be obtained.
The United States Patent Office is a bureau of our govern ment, established ostensibly for the protection of the citizens
who, by their superior knowled re or by the exercise of their who, by their superior knowled,re or by the exercise of their
inventive faculties, are able to produce any new and useful art, machine, manufacture, or composition of matter, or any
improvement upon any art, machine, manufacture, or com position of matter, and sharl under certain conditions liave a pa-
tent therefor which shall, for a stipulated number of yeurs give them the exclusive right to malse and sell the same. This
bureau is by law self-sustaning; it is not and can not be any bureau is by law self-sustaining; it is not and can not be any
expense to the government, but the funds for its support are raised by a tax or charge made against each individual who applies for a patent, and it, is out of the fund thus created here that the inventors are taxed upon whatever property
they may own in all respects like oth'r citizens, and that the tax for examining their in
which no one else is subject.

Of the fund thus creaed there is now in the Treasury of
the United States, to the credit of the Patent Office, nine hundred thousand dollars or more, which shows that the
hand hundred thousand dollars or more, which shows that the
the is more than is necessary for the maintenane of
the bureau. It does not seem to admit of a doubt that the
money alluded to as in the United State 8 Treasury is in equity else; and it is believed that the most daring financier of the
times would hesitate to say that it could equitably be applropriated for any purpose outside of oue that would bet directly
in furtherance of their interests. Holding, as I do, that this
fund must either be spent for the benefit of inventors or

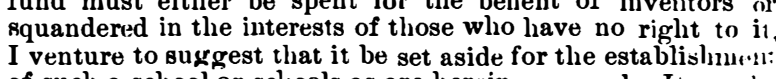
of such a school or schools as are herein proposed. It may in
said that the amount is not enough to establish such a scho.. and to sustain it when in operation; but to this view may be build all the necessary buildings for two or three such in
itutions, and to furnish them with all the applisnces necesstitutions, and to furnish them with all the applisnces neces-
sury for the prosecution of the studies of those placed therein,
and that the interest upon the romainder, and the small mount of tuition-fees that could properly be charged
would furnish the funds to keep them in succissful operation; and should this not be the case, Congress could
; make an appropriation therefor, witlout its bein $\div$ the most
reprelhensible act that it ever committed. The writer is aware that polytechnic schools in which many branches of art r science are taught are in existence in many countries, in-
luding our own; but they do not comprehend all that he

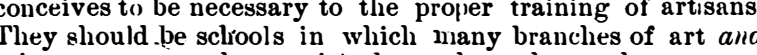
science are taught conjointly rather than wher many
branches of art or science are tanght, in order that all the training which the most skilful artisan requires can be ob-
tained. This, being our Centennial year, seems to be an appropriate time to move in this matter, and as it is presumed that alive will be there, it is suggested that they meet in their reconvention to be called by said deleyates at some suitable
period during the contin uance of the Exposition at Philadel period during the contin uance of the Exposition at Philadel-
phia, to consider the propriety of petitioning Congress for an pose stated.

Before closing this article I desire to appeal to the invenBefore closing this article 1 desire to appeal to the inven-
ors of this great country not to let this opportunity pasa un-
mproved, it being as farorable a one as is likely to present tself for insisting that the money which is now on hand chat which has been taken from them, and all that may ac-
crue from the same source in the future, slanl be placed selves a monument in the form of such a place of training for o such uses for all time. Let us as one man join in asking

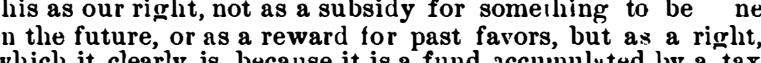
evied upon the few for their benefit and not for the benefit of the many; were it ctherwise, jt would be contrary to the
spirit of the institution and the fundamental laws of the I fird that as early as March 3d, 1849, fifty thousand dollars was appropriated from the Patent Office fund for the erection
of the building in which the office is located; and it is clear to me that the government ought to refund that amount and all others that have been thus appropriated, with interest upon the same up to the time when it is paid. 1838 the receipts of the Office were $\$ 4721.44$ more
the year 183 mon the $\$ 21,795.65$; from which frat some to idea can be gathered of the mount of interest that has accrued upon the amounts thu accumulated. Let me express the hope that edicurs to whose
knowledge this proposition may come will in their own way
bring it to the attention of their readers, in order that the bring it to the attention of their readers, in order that the
parties interested may act upon the lints presented, if in their judgments it shall seem best.
Much more could with propriety be said upon this subject. but as it is only designed at the present time to direct attell-
tion to this subject, more need not be said except to inform any person interested that shlould any facts or figures be re-
quired in relation to this fund, the writer will cheerfully un quired in relation to this
dertake to furnish them.

\section{GOLD IN INDIA.}

The Madras newspapers have lately given some account
the Colar gold-fields. in Mysore, and of the operations of the Colar gold-fields. in Mysore, and of the operations
which have just been commenced there by the Ooregum GoldMining Company. T'he auriferous quartz reefs are said to extend for a length of nearly twenty miles, and are only about
twelve miles distant from a station on the Madras Rail way. The company has already sunk one main and two auxifiary shafts, the former of which is expected to cut the reef at
abrut 60 feet. The works have been so recently begun that it is not yet possible to form any accurate idea as to the prob-
able results, but it seems to be thouglht that the field is one of great richness; moreover, it has a history which is s:id to
go as far back as the year 1293, when Allageen, a general in the service of the Emperor of Delhi, returned from an in vasion of Mysore, bringing with him a large amount of gold.
Hyder Ali and Tippoo Salib would also appear to have worked the mines. Should it turn out that the reefs can be
profitaly worked, the facts that they are situated at an eleless tempt many Europeans to try their fortunes there.

NEW SUBSTITUTE FOR GOLD.

THE following is a new metallic alloy which is now very copper, 100 parts; zinc, or preferably tin, 17 parts ; magnesia

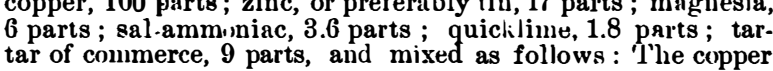
is first melted, then magnesia, sal-ammoniac, lime, and tartar
are ydded separately and by degrees, in form of powder. 'l'he are ndded separately and by degrees, in form of lowder. 'l'he
whole is next stirred briskly for ybout lalf an loour so as to mix thoroughlyly, alter which the zinc is addiel in small grains
by throwing it on the surface and stirring it until it is enby throwing it on the surface and stirring it until it is en-
tirely fused. On this being done the crucible is then covered
and the fusion maintained for about 35 minutes, after which and the fusion maintained for about $3 \tilde{5}$ minutes, after which
the surface is skimmed and the alloy is ready for casting. the surface is skimmed and the alloy is ready for casting.
T'tis alloy has a fine grain, is malleable, and takes a splendid polish. It does not corrode readily, and for many purposes

London, April 1.-In consequence of the dulness of trade all the ironworkers of the great Sheepbridge, Atlas, and Cyclops Iron Works, in slieffield, have been discharged.
The employees of the Phoenix and Dronfield Bessemer-Steel Works lave agreed to accept a considerable reduction instend 